\title{
Developing Entrepreneurial Skills and Transforming Challenges into Opportunities in Nigeria
}

\author{
Dr. Odia J.O. (PhD, ACA) \\ Department of Accounting, \\ University of Benin, Benin City, Nigeria. \\ odiajames@yahoo.com, 08056580011 \\ Odia. A.A. (M,Sc.ed,) \\ (Ph.D Student), Department of Education Psychology \& Curriculum studies, \\ University of Benin, Benin City, Nigeria. \\ odiaagnes@yahoo.com, 08138865461
}

\section{Doi:10.5901/jesr.2013.v4n3p289}

\begin{abstract}
The paper considers developing entrepreneurial skills and transforming challenges into business opportunities in Nigeria.Today, the twin challenges of unemployment and poverty are facing graduates of tertiary institutions and professionals owing to the global economic meltdown and economic recessions in most countries including Nigeria. While the government braces up to these challenges through the various programmes and entrepreneurial initiatives, a key solution is the equipping of graduates and professionals with entrepreneurial skills which can make them employable and become employers of labour. Again the paper advocates that besides the possession of entrepreneurial skills, knowledge and hard work, the would- be entrepreneurs must have the right attitude if they are to succeed in transforming challenges into profitable business opportunities. Moreover, the governments and corporate bodies in Nigeria must support by investing in entrepreneurial education in Nigerias
\end{abstract}

Keywords: Entrepreneurship, skills, opportunities, unemployment

\section{Introduction}

In today's world, the stack reality is that for university graduates and other professionals, job competition and unemployment are becoming stiffer and tougher. Unfortunately, government's response to the unemployment problem is slow, inadequate and not radical. There is also an urgent need to bring back the middle class in the society which has been lost for many years. Fresh university graduates and professional accountants used to be classified in the past as being in the middle class but today they are in the lower class. The only genuine channel of restoration is entrepreneurship characterized by sustained job and wealth creation. The unemployment market is bloating every year. For instance, the unemployment rate of Nigeria was put at about $19.7 \%$ above world average of $14.2 \%$ by the World Bank, with $41.6 \%$ unemployment rate reported for youth in the 18 to 24 years age bracket Similarly, over fifteen states in Nigeria were above the National unemployment average in 2009 (see table 1). The unemployment rate for 2011 stood at 23.9\% translating to about 40 million of the population and the average youth unemployment rate was an appalling 46.5\% (Lemo, 2013). Recently, the National Bureau of Statistics put the unemployment rate in the first quarters of 2013 at $23.9 \%$. And given the Nigerian youth unemployment situation, entrepreneurship remains the viable option to create jobs, reduce unemployment, poverty and empower the youths to develop their businesses, pursue their dreams and contribute to overall productive capacity and national economic growth and development (Lemo,2013). Again among thousands of tertiary institutions graduates in Nigeria every year, only a few hundred of them are lucky to secure paidemployment. Hence, going through the higher institutions of learning and/or possessing professional qualifications in disciplines like accounting, law, engineering and medicine is no longer a guarantee to getting the desired employment because of the shrinking economy. However, the way out is through encouraging the development of entrepreneurial skills which can help them to transform the challenges into business opportunities. 
This rest part of the paper is divided into five sections. Section I looks at the challenges of today's graduates and professionals. Section II highlights the concept and definition of entrepreneurship, characteristics of entrepreneurship, and elements of entrepreneurship, entrepreneurial opportunities and some of the legal frameworks the would-be entrepreneur should be familiar with in conducting his business in Nigeria. Section III dwells on the relevant entrepreneurial skills and how to develop these skills. Section IV shows the characteristics of a dwindling economy and the role of entrepreneurship in a dwindling economy. Section $V$ is the conclusion.

\section{Challenges of Today's University Graduates / Professionals}

The importance of the development of entrepreneurial skills by every graduate accountant cannot be over-emphasized because gone are the days when jobs were available everywhere both in the private and public sectors of the economy and employers go about looking for potential employees to employ. Indeed, in the past, it is the employers who go round universities and polytechnics to hunt for potential graduates for employment. Then there were fewer universities and polytechnics and the enrolment was also low then. But today, things have changed to the extent that many graduates of tertiary institutions are now sellers of recharge cards or work as bus conductors. What a tragedy and economic waste! The question of choice of job or the type of employer is gradually being eroded each year as the white-collar jobs are scarcely available. Hence many graduates are desperate to get any job to keep body and soul together. Indeed there is a paradigm shift in the labour market. Even the professional disciplines like accounting, medicine, law and engineering to mention are few are now fast getting into tight employment opportunities.

Employment prospects amongst qualified accountants are becoming increasingly competitive and the job openings are equally limited. From our experiences, many graduate accountants have strong preference for the industry or private sector practice but things have since changed as employment opportunities in the private sector are decreasing. Indeed job prospects are diminishing by the day in both the private and public sectors. Added to this ugly situation is the increasing trend of job outsourcing in accounting and consultancy firms, casualization of labour in the oil and gas industry and the increasing phenomenon of rightsizing of labour among big firms and corporations in the country. As a consequence, the figure of tertiary graduates who have not been able to secure the first employment since upward of 5 years after graduation is on the rise and even those with masters and professional qualifications like: Medicine (NMA), Law (NBA), Engineering (COREN) and Accounting (ICAN) are not spared from this ugly socioeconomic phenomenon. Some accountants are even paid peanuts if they are lucky to secure paid jobs. University and polytechnics accounting graduates now fall back on their lower qualifications like the School Certificates, National Diplomas (ND) and Polytechnics (OND and HND) to secure menial jobs.

The recent global economic meltdown has made matters worse. Some companies are operating below capacity level. The current troubles in the financial sector, particularly the money and the capital markets and the subsequent effects on the economy are not only visible but highly challenging as far as employment is concerned. We believe there is still need for reforms in financial sector particularly the banking sector. Another round of merger or acquisition will definitely happen. Such moves are always accompanied by both positive and negative consequences when labour is involved. There is also the need to encourage very strongly the development of the micro-finance institutions in order to encourage small scale business owners. The real sector like Agriculture and the manufacturing sectors have been neglected for too long. Theyhave not been given adequate attention since the advent of oil in the 1970s.

Entrepreneurship and entrepreneurship education have been suggested to help redress the problems of unemployment and poverty among the teeming youths and graduates in Nigeria as they will make them not only to be job creators but also wealth creators (Midea,2004, Izedonmi,2009,Unachukwu,2009). According to Small Business Service (2005), "the possession of entrepreneurial skills to create new knowledge based social enterprises is vital to addressing these social and environmental issues effectively". In the face of the global meltdown, entrepreneurship is a central pillar to economic growth and development, employment generation and poverty alleviation (Unachukwu, 2009). Hence, our nation cannot afford to toy with the issue of entrepreneurship, entrepreneurial skills acquisition and development. Our tertiary institutions must respond fast and positively towards entrepreneurship education. Graduates should be encouraged to undergo vocational education during the one year mandatory National Youth Service Corp (NYSC) for those below 30 years. In fact, part of NYSC should be spent in government well-equipped skills and vocational training centres and well as attachees to private organization where they could acquire entrepreneurial skills.Universities and polytechnics should have entrepreneurial skill development and acquisition centres for students training. However, the general business skills and knowledge in the current tertiary institutions curricula are considered insufficient to turn graduates into serious-minded entrepreneurs (Kisby, 2004). Therefore, the need to acquire and 
develop specific entrepreneurial skills cannot be overemphasized because entrepreneurship is vital to creating employment and indeed a special form of employability for graduates (Moreland, 2004).

\section{Entrepreneurship in Nigeria}

According to Ekanem (2005), the history and development of entrepreneurship in Nigeria started in the 1960s. This is confirmed by some of the earlier studies such as Schatz and Edokpayi (1962), Harris (1969), Olakanpo (1968) and Akeredolu-Ale (1975). Therefore, the concept of entrepreneurship development in Nigeria is not entirely really new. Since the 1970s for example, several government agencies and institutions in the country have been engaged in different aspects of fostering entrepreneurship though with short-lived and varied successes. For instance, Entrepreneurship Development Center (EDC), Centre of Management Development (CMD),National Directorate of Employment (NDE), former Nigeria Industrial Development Bank (NIDB), Nigerian Bank for Commerce and Industry (NBCl),Nigerian University Commission (NUC), Nigeria Youth Service Corps (NYSC), National Economic Empowerment and Development Strategy (NEEDS), National Open Apprenticeship Scheme (NOAS) and the Small and Medium Enterprise Development Association of Nigeria (SMEDAN), Small and Medium Enterprises Equity Investment Scheme (SMEEIS) among others have programmes for entrepreneurship development and skills acquisition in Nigeria. SMEDAN was established by the small and medium industries development Act, 2003 to promote the development of the Micro, Small \& Medium Enterprises (MSMEs) sector of the Nigerian economy and their access to resources required for their growth training and development. SMEEIS is the banking industry's contribution to the Federal Government's efforts towards stimulating economic growth, developing local technology and generating employment through adequate entrepreneurial development policies. Besides some State and Local Governments entrepreneurial and skill acquisition efforts, the Subsidy Reinvestment and Empowerment Programme (SURE-P), the Young Entrepreneur, the Youth Enterprise with Innovation in Nigeria (YouWIN) and the Graduate Internship Scheme (GIS) programmes of the Federal Government in 2012 are meant to promote entrepreneurship skills and reduce unemployment in Nigeria. Other entrepreneurial development agencies include government sponsored Entrepreneurial Development Programmes (EDP), various shades of non-governmental organizations (NGOs) and Nigerian Employer's Consultative Association (NECA) initiatives.

The menacing problem of unemployment and poverty spurred the Nigerian government into developing a policy framework for youth entrepreneurship education. This resulted in the birth of the National Directorate of Employment (NDE) in 1986 and the Work For Yourself Programme (WFYP) in 1987.Both programmes provided training and financial support to entrepreneurs. The NDE grooms unemployed youths and retired persons in vocational skills, entrepreneurship/business development, labour-based works, rural employment promotion and job placement guidance and counselling. The NDE includes core four programmes such as: youth employment and vocational skills development programme agricultural employment programmes and the small scale industries and graduate employment scheme and Special Public Works programmes (Nigeria Rural Development Sector Strategy Main Report,2004). Ebiringa (2012) argues that several policy interventions in Nigeria that were aimed at stimulating entrepreneurship development via small and medium scale enterprises failed and advocated a more inclusive approach. Lemo (2013) argues that improper orientation of youths, weak institutional capacity, lack of social safety nets policy, disconnect between academic qualifications and work process and improperly-focused budgetary provisions were some of the challenges responsible for the failure to achieve the objectives of the various schemes.

\subsection{Entrepreneurship Education}

The first graduate course in entrepreneurship was offered at Harvard University by Professor Miles Mace in 1947 (Katz,2003,Vyakarnam (2009). Fry (1992) observes that entrepreneurship has been one of the fastest growing disciplines in the U.S.A in the 1990 s. Indeed by the wake of the $21^{\text {st }}$ century, as many as 1600 universities in the NorthAmerica were found to be offering different courses in entrepreneurship when compared to merely two dozen in the 1970s (Inegbenebor,2005). In the U.K, the first few courses in entrepreneurship were launched in the 1980s together with the UK's first initiative for enterprise in higher education (Elton, 1991,Kirby, 1989 \& 2005,Volkmann, 2004). The growth of entrepreneurship education and the subsequent inclusion of the discipline into the curricula of universities in the United Kingdom have been attributed to the sheer need to serve the innovation need of businesses and to produce graduates with transferable skills for businesses.

The need for entrepreneurship education started in Nigeria in the mid 1980s when the economy collapsed due to political instability and inconsistencies in the social-economic policies of successive governments. This resulted in very 
high youth and graduate unemployment (Arogundade, 2011). Graduates of tertiary institutions were not having sound knowledge and skills which would make them self-reliance. The lacuna led to the introduction and emphasis on entrepreneurial education owing to the belief that its introduction into tertiary education would lead to acquisition of skills that would enable its graduates to be self reliant and consequently reduce unemployment problems (Nwangwu, 2006). Arogundade (2011) argues entrepreneurship education will equip the students with the skills to be self-reliant and task the government and other education stakeholders should make sure that educational programme at all levels of education are made relevant to provide the youths and graduates needed entrepreneurial skills. Entrepreneurship education in the narrower sense follows a direct approach, developing students' competences and entrepreneurial intentions towards starting a business as a career option.

According to Paul (2005),the objectives of entrepreneurship education include to : (1) offer functional education to youth to make self-employed and self-reliant.(2) provide youth graduates with adequate training to them creative and innovative in identifying novel business opportunities and establish a career in small and medium scale businesses (3).reduce high rate of poverty and rural-urban migration (4) create employment and serve as a catalyst for economic growth and development among others. The challenges to the promotion of entrepreneurship education include: inadequate capital, unstable macro-economic environment, risk adversity of people, low infrastructural development etc (Ayodele, 2006). Unachukwu (2009) identifies the challenges to entrepreneurship education in Nigeria to include: finance, manpower and education, data, inadequate infrastructures and entrepreneurial attitude. She advocates the need for entrepreneurial education for the youth. The government at all tiers, the Nigerian Universities Commission (NUC), professional bodies like ICAN and the academia have been attracted to it. In particular, some universities are redesigning their curricula and the ways they operate to create opportunities for the training of their students in practical entrepreneurial skills. The Federal Government of Nigeria issues directive through the Nigerian Universities Commission (NUC) to all Universities in the country to establish centres for Entrepreneurship Development to coordinate the offering of a benchmark entrepreneurship course to all students in Nigerian universities. Therefore, the NUC has made course on entrepreneurship development (CED) to be mandatory for all Nigerian graduates irrespective of their disciplines since year 2000.The strategic objectives of the national policy are to: (1) improve the capacity of youths to develop positive independent and innovative thought process and overall entrepreneurial mind-set and (2) the development of vocational skills to stimulate future graduates towards venture and wealth creation..A recent survey of university undergraduates on their perception of CED by one of the authors reveals these objectives might be far from being achieved given the present traditional model. However ,due to the way entrepreneurial programmes have assumed a global proliferation and dimension, it was suggested by Volkmann (2004) that entrepreneurship will become "the major academic discipline for business education in the $21^{\text {st }}$ century".

Table 1. Unemployment rates in Nigeria's States

\begin{tabular}{|c|c|c|c|c|c|}
\hline State & Rate (\%) & State & Rate (\%) & State & Rate (\%) \\
\hline Abia & 14.5 & Ekiti & 20.6 & Nasarawa & 10.1 \\
\hline Adamawa & 29.4 & Enugu & 14.9 & Niger & 11.9 \\
\hline Akwalbom & 34.1 & Gombe & 32.1 & Ogun & 8.5 \\
\hline Anambra & 16.8 & Imo & 20.8 & Ondo & 14.9 \\
\hline Bauchi & 37.2 & Jigawa & 26.5 & Osun & 12.6 \\
\hline Bayelsa & 38.4 & Kaduna & 11.6 & Oyo & 14.9 \\
\hline Benue & 8.5 & Kano & 27.6 & Plateau & 7.1 \\
\hline Borno & 27.7 & Katsina & 37.3 & Rivers & 27.9 \\
\hline Cross River & 14.3 & Kebbi & 12.0 & Sokoto & 22.4 \\
\hline Delta & 18.4 & Kogi & 19.0 & Taraba & 26.8 \\
\hline
\end{tabular}




\begin{tabular}{|c|c|c|c|c|c|}
\hline Ebonyi & 12.0 & Kwara & 11.0 & Yobe & 27.3 \\
\hline Edo & 12.2 & Lagos & 19.5 & Zamfara & 13.3 \\
\hline
\end{tabular}

Source: National Bureau for Statistics (2009)

\subsection{Recent entrepreneurial initiatives by the government in Nigeria}

Development Finance Institution (DFls) was set up by the Federal Government of Nigeria at various times to encourage the entrepreneurial developments which were in the form of small and medium scale businesses in Nigeria (Osemeke,2012). The DFIs include: (i) The Nigerian Agricultural, Co-operative and Rural Development Bank (NACRDB) (ii) Nigeria Export-Import Bank (NEXIM) (iii) The Federal Mortgage Bank of Nigeria (FMBN) (iv) Bank of Industry (BOI) and (v) Urban development Bank of Nigeria (UDBN). Recently, SMEDAN has begun training of graduates under National Youth Services Corps (NYSC) on investment and entrepreneurial skills under the Corpers' Entrepreneurial Programme (CEP) to help the exploitation of the opportunities that abound in the country's small-scale industry. Some of the current interventions by the government to positively engage the youths in national development through encouraging entrepreneurship and providing employment include:

1. The N200 billion Micro, Small \& Medium Enterprises (MSMEs) Development Fund to provide cheap and longterm financial resources for the development of the MSMEs sector in Nigeria;

2. The N100 billion Textile Revival Fund (TRF) for the resuscitation of the cotton, textile and garment Industries which has been comatose and moribund;

3. The Public Works and Women/Youth Empowerment Scheme (PW/WYE) was launched by the Federal Government of Nigeria to create immediate employment opportunities for women and youths in labourintensive public works;

4. The Youth Enterprise with Innovation in Nigeria (YouWIN) programme is a collaboration of the Federal Ministries of Finance, Communication \& Technology and Youth Development to organise an annual Business Plan Competition (BPC) for aspiring young entrepreneurs in Nigeria and provide a one-time equity grant of N1 to N10 million to 1,200 selected aspiring entrepreneurs to start/expand their business concepts and mitigate start up risks. It is aim at generating some 80,000 to110,000 new jobs for unemployed Nigerian youths over a three-year period.

5. The Niger Delta Amnesty Training Programme has been engaged in the training of youths at various institutions in Ghana, South Africa, the Philippines, Russia, Ukraine, India and elsewhere. Also, more than 5,000 youths have been enrolled in formal educational institutions and vocational centres within and outside the country. To date, over 5,000 beneficiaries have graduated in such skill fields as welding \& fabrication, entrepreneurship, pipe-fitting, carpentry \& plumbing, oil drilling, electrical installation, ICT, and marine-related vocations.

6. Petroleum Technology Development Fund (PTDF) was established to promote and upgrade petroleum technology and manpower development through research and training of Nigerians as graduates, professionals, technicians and craftsmen in the fields of engineering, geology, geo-sciences, management, economics and relevant fields in the petroleum and solid minerals sectors in Nigeria and other countries of the world.

7. The NYSC Venture Price Competition was introduced by the CBN to sensitize and create awareness in Nigerian youths, awaken their entrepreneurship expertise and orientate serving youth corps members towards seeking alternative employment options, in particular, self-employment.

8. The N200 billion Commercial Agriculture Credit Scheme (CACS) finances large ticket projects along the agricultural value chain, in addition to the older Agricultural Credit Guarantee Scheme (ACGS). The CACS has disbursed over N158.39 billion for 203 projects owned by 175 private promoters and 27 state governments \& the FCTA, with 5,910 jobs created.

9. The Nigeria Incentive-Based Risk Sharing System for Agricultural Lending (NIRSAL) is a partnership of the CBN, UNIDO and Alliance for a Green Revolution in Africa. It was developed to boost access to bank financing for agriculture by de-risking the agricultural and financial value chains through the adoption of risksharing approaches.

10. The N200 billion Refinancing/Restructuring of SME/Manufacturing Fund to enable banks refinance and restructure their existing loan portfolios to SMEs and manufacturing firms. 
11. The Power \& Aviation Intervention Fund (PAIF) has disbursed some N144.60 billion to Deposit Money Banks (DMBs) for 10 power and 11 aviation projects as well as generated numerous jobs.

12. The N200 billion Small \& Medium Scale Enterprises Guarantee Scheme (SMECGS) of the CBN promotes further SME access to credit. In barely two years, the scheme has disbursed over N1 billion to 20 qualified applicants with attendant boosts in their businesses and employment generation.

13. The young entrepreneur scheme of the Federal Government of Nigeria.

\subsection{Entrepreneurial Skills Require to Transform Challenges into Business Opportunities}

Despite the fact that entrepreneurship training is supposed to promote the "development of personal qualities such as creativity, risk-taking and responsibility and provide the technical and business skills that are needed in order to start a new business venture" (EU,2002), there are concerns that many training institutions offer very little entrepreneurial skills in South Africa (Ladzani \& Van Vuuren, 2002, Isaacs et al,2007). Therefore, Ladzani \& Van Vuuren (2002) propose the content of entrepreneurship training to consist of: motivation, entrepreneurial skills and business skills since the degree entrepreneurship is found to be dependent on three dimensions such as innovativeness, risk-taking and proactiveness (Morris \& Kuratko, 2001). Because entrepreneurship can be learnt (Timmons \& Spinelli, 2004) and embraced by many tertiary institutions in USA, Europe, East Asia and Latin America (Kuratko, 2003), entrepreneurial skills to be taught should include creativity and innovation, ability to take risks, identify business opportunities (Ladzani \& Van Vuuren, 2002).

Table 2. Content of entrepreneurial performance training

\begin{tabular}{|l|l|l|}
\hline \multicolumn{1}{|c|}{ Motivation } & \multicolumn{1}{|c|}{ Entrepreneurial skills } & \multicolumn{1}{c|}{ Business skills } \\
\hline - Need for achievement & - Creativity & - Management/ Leadership \\
- Ability to inspire & - Innovation & - Business plans \\
- Expectations of the higher achiever & - Ability to take risks & - Financial skills \\
- Obstacles or blocks & - Ability to identify opportunities & - Marketing skills \\
- Help & - Ability to have a vision for growth & $\bullet$ Operational skills \\
- Reactions to success or failure & - Interpret successful entrepreneurial & - Human Resources skills \\
& role models & \\
\hline
\end{tabular}

Source: Ladzani \& Van Vuuren (2002)

A) General Business Skills - Some common or major entrepreneurial skills of successful entrepreneurs are identified below namely: Sales and marketing skills, prudent money management or sound financial Knowhow skills, very strong self-motivation skill, effective time management skill, and high and flexible administrative skill. If you watch very closely a lot of these skills have to do with the person, the ideas, products and services. In fact, until people accept you, they may never accept your product or service. We shall briefly elaborate these points.

B) Sales and marketing skills- To attract the right customers maintain their loyalty and subsequently make target revenues and profits will obviously require good communication skill.

C) Financial know-how skills and money management- Not many people can manage or handle money .There are others who money can control. Some become temporarily insane when they see a volume of money they have never seen before. To succeed as an entrepreneur, you must know how to

- Manage money well. After all, not everybody can effectively manage money. Money actually controls some people.

- Source for funds from the right sources at the right time and the right cost of capital. Funds include longterm capital and working capital

D) Self-motivation skills- Encouragement from others is good but self-encouragement is the best. You need it in your journey into entrepreneurship. You can motivate yourself even if people around you want to discourage or disappoint you. Self motivation skills include: internal locus of control, self-starter with a clear desired goal in mind, confidence in yourself and in your ideas, diligent and hardworking and extra drive and commitment to set goals

E) Time management skills- Successful entrepreneurs must manage their time effectively. This is because: (1)Time is money.(2)Time is life (3) Entrepreneurship opportunity has time-limit (4) Time management is very 
important for business success and (5) Self-management is very critical for effective time management. The key to using time effectively is through better management. Entrepreneur achieves better time management through time budgeting. The specific ways to make better use of his time include: establishing goals, determine deadlines and allocating time for each important activity (Osemeke,2012).To manage time the entrepreneur must: (1) Have a time table or schedule of activities to be done and keep to it as much as possible (2) Employ delegation freely without fear. The entrepreneurs must determine priorities into urgent and important activities as: i -Urgent activities that demand immediate attention ii -Urgent but not important activities iii - Not urgent but important activities iv -Not urgent; not important.

They must give priority to (i) and (iii) because by performing them time is reduced for activities (ii) and (iii), and manage meetings and relationships with others as entrepreneurs.

F) Administrative skills- Administrative skills include: organizing, coordinating, directing, planning and general management etc.

G) Technical, analytical and Human relation skills- Accountants are by training normally technically skilled. They must also develop and possess conceptual, analytical and human relation skills to be successful entrepreneurs. Others are business planning, idea generation, negotiation and risk analysis and management skills.

H) ICT Skills- Graduate entrepreneurs should have Computer and ICT skills because of the era we live in, the dynamic environment they will have to operate on day to day basis and the various technological changes and demands they will face.

Table 3. Entrepreneurship Opportunity and Skills

\begin{tabular}{|c|l|l|}
\hline S/N & \multicolumn{1}{|c|}{ Entrepreneurship Opportunity } & \multicolumn{1}{c|}{ Skills And Attitudes } \\
\hline 1. & $\begin{array}{l}\text { Business/consultancy in areas of } \\
\text { professional specialization or working } \\
\text { as a contractor }\end{array}$ & $\begin{array}{l}\text { - General Business skills such as marketing, time management etc } \\
\text { - Confidence enthusiasm, hardworking }\end{array}$ \\
\hline 2. & Sonet entrepreneurship & $\begin{array}{l}\text { - Idea development, leadership, negotiation, planning, organizing, self } \\
\text { belief, confidence } \\
\text { - General business skill }\end{array}$ \\
\hline 3. & Intrapreneurship & $\begin{array}{l}\text { - Idea development recognizing opportunities for improvements } \\
\text { - Alliance building, confidence, leadership }\end{array}$ \\
\hline 4. & Non-traditional specialist business & $\begin{array}{l}\text { - General Business } \\
\text { - Idea development, creativity, confidence } \\
\text { - Willingness to work hard }\end{array}$ \\
\hline 5. & General business ventures & $\begin{array}{l}\text { - Ideas development, creativity, confidence, willingness to work hard } \\
\text { - General Business skill }\end{array}$ \\
\hline
\end{tabular}

Source: Andrea,F (n.d): Developing entrepreneurship skills in the context of higher education. http://cfiweb.cf.uk/news /past.events/bee/files/Andea. on 16/3/2010

\subsection{Avenues for Developing Entrepreneurial Skills}

Entrepreneurial skills acquisition can be obtained through various avenues such as: attending entrepreneurial training classes, development programmes, seminars, workshops, etc. universities, job rotation, special (intensive) training, articleship or apprenticeship,organizational learning, R \& D Institutions, consultants, national and international agencies and bodies ,non-governmental organizations (NGOs) and professional bodies.

The Federal Government of Nigeria under the Subsidy Reinvestment and Empowerment Programme (SURE-P) launched the Graduate Internship Scheme (GIS) in October, 2012 to create opportunity for 50,000 graduates to be attached to firms /organizations, where they can work for a year and enjoy a monthly stipend of N18,000.The GIS is meant to provide the opportunity to unemployed Nigerian graduates to gain working experience during a period of one year and enhance their employability in the labour market, get retained by their firms of engagement, or even seek other opportunities through other government programmes like the Youth Enterprise with Innovation in Nigeria (YouWin) where they can develop business plans and get loans to run their businesses independently (Suleiman,2013). The expected 
outcomes of the GIS include: increased skills of youth, increased number of interns employed or engaged in selfemployment and increased Small and Medium Enterprises (SMEs) in Nigeria.

The specific objectives of the GIS program are:

1. To enhance the employability of up to 50,000 unemployed graduates in the 36 states of the Federation and the FCT through internship programs in pre-selected institutions; and

2. To reduce the vulnerability of unemployed graduates.

3. To build manpower base towards attaining national development operations.

The benefits to interns include:

1. Provide them with skills and information required to enter into work.

2. Empower youth to work for themselves or create jobs for others.

3. Protect youth from demand and supply shocks through acquisition of skills.

4. Opportunity to sharpen their skills and enhance employability.

5. Opportunity to build new networks and professional contacts.

The interns are to use the opportunity to make them very competitive, enterprising, smart, knowledgeable and portray themselves as indispensable brands to the labour and the business market (Papka, 2013).

The benefits to firms/organizations include:

1. Build human capital prepared for current and future labour demand.

2. Be part of building manpower base for natural development and enhance our attainment of Vision 20:2020.

3. Opportunity to recruit talented interns after graduation from the GIS.

\subsection{Entrepreneurial Success Factors}

Successful entrepreneurship depends on four (4) major factors namely: Knowledge, Hard work, Skills, Attitude (character/ integrity). Now let us work out this "lifematics" question together. For easy understanding, let us replace character with attitude. Our current alphabets (A-Z) and numerals (1-26) are made up of letters. The alphabets together with their corresponding numerical values are stated below:

\begin{tabular}{|c|c|c|c|c|c|c|c|c|c|c|c|c|}
\hline A & B & C & D & E & F & G & H & I & J & K & L & M \\
\hline 1 & 2 & 3 & 4 & 5 & 6 & 7 & 8 & 9 & 10 & 11 & 12 & 13 \\
\hline $\mathbf{N}$ & $\mathbf{0}$ & $\mathbf{P}$ & $\mathbf{Q}$ & $\mathbf{R}$ & $\mathbf{S}$ & $\mathbf{T}$ & $\mathbf{U}$ & $\mathbf{V}$ & $\mathbf{W}$ & $\mathbf{X}$ & $\mathbf{Y}$ & $\mathbf{Z}$ \\
\hline 14 & 15 & 16 & 17 & 18 & 19 & 20 & 21 & 22 & 23 & 24 & 25 & 26 \\
\hline
\end{tabular}

Let us take each attribute one after the other and link up the corresponding numerical value. Start with skill, then knowledge, hard work and finally character (attitude)

Let match the numeric value to each alphabet and see the results as indicated below:

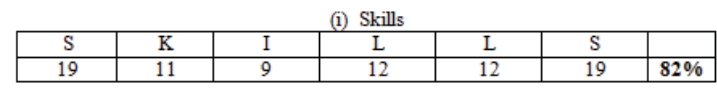

\begin{tabular}{|c|c|c|c|c|c|c|c|c|c|}
\hline $\mathrm{K}$ & $\mathrm{N}$ & $\mathrm{O}$ & $\mathrm{W}$ & $\mathrm{L}$ & $\mathrm{E}$ & $\mathrm{D}$ & $\mathrm{G}$ & $\mathrm{E}$ & \\
\hline 11 & 14 & 15 & 23 & 12 & 5 & 4 & 7 & 5 & $96 \%$ \\
\hline
\end{tabular}

\begin{tabular}{|c|c|c|c|c|c|c|c|c|}
\hline H & A & R & D & W & O & R & K & \\
\hline 8 & 1 & 18 & 4 & 23 & 15 & 18 & 11 & $98 \%$ \\
\hline
\end{tabular}

\begin{tabular}{|c|c|c|c|c|c|c|c|c|}
\hline A & T & T & I & T & U & D & E & \\
\hline 1 & 20 & 20 & 9 & 20 & 21 & 4 & 5 & $100 \%$ \\
\hline
\end{tabular}

Skills score only $82 \%$; knowledge $96 \%$, hard work $98 \%$ and Attitude (character) scores $100 \%$. Only attitude which equates to character or integrity for this purpose secures $100 \%$ success in the race of high profile entrepreneurship. Others like skill (82\%), expertise, knowledge (96\%), hardwork (98\%) and finance (52\%) are critical but they all still bore down to attitude, because without the right attitude, the entrepreneur and the enterprise will fail sooner or later. Hence, attitude is everything (Harrel,2005) backed with the requisite entrepreneurial skills. 


\section{Conclusion}

In conclusion, it must admit that possession of university or professional certification by tertiary institutions in Nigeria is good. But what is the use of academic degree(s) and/or professional certificate(s) if the graduates are not working or unemployed. You either work for others and get paid or create work yourself entrepreneurially and pay yourself. Whichever mode of value creation either paid employment or entrepreneurship you may adopt at the end you really require integrity. Indeed, character is the true collateral security of our values, learning and entrepreneurial successes. It keeps the society and system going. It prevents a nation from decaying and checkmates unnecessary crises and even civil disorder and war. Therefore in all your entrepreneurial pursuits and skill acquisition, character development should be given a prominent place. When character breaks down, everything breaks down. True certification in life is only evidenced by sound character and not papers called certificates, entrepreneurial success alone or by the quantity of wealth. The present state of entrepreneurship education in Nigeria mark by under-funding, negligence, lack of political will, support and investment by government and corporate bodies to invest in education cannot produce graduates who are employable or having the ability employ others. Given the various challenges the facing the country and her teeming unemployed graduates of tertiary institutions and professionals today, the sure remedy is not only the possession of certificates but the development of entrepreneurial skills which could help them identify and take advantage of the numerous business opportunities. Moreover, the entrepreneur education in Nigeria should re-focus the teaching and training of students towards inculcating entrepreneurial skills that can help to be creative, innovative develop feasible business plans and set up new business ventures. The Graduate Internship Scheme of the SURE-P is a welcome idea in equipping graduates with the requisite skills and should be sustained and massively supported by the government to fulfill its objectives. However, the GIS should not be medicine after death by making the Nigerian graduates to waste another year after the NYSC scheme. It should be infused into the entrepreneurship training programmes in the tertiary institutions and the Federal Government through the SURE-P and corporate bodies in Nigeria partnership by supporting the project through adequate funding of entrepreneurship education, provision of fully equipped entrepreneurship centres and facilitators vocational training and internship for undergraduates of universities and colleges.

\section{Acknowledgement}

The authors wish to thank the Institute of Chartered Accountants of Nigeria (ICAN) for the invitation to present this (modified) paper at the induction ceremonies for the Institute graduates in May, 2010 and November, 2010.

Dr. Odia , J.O. (Ph.D, ACA) is a lecturer in the Department of Accounting, University of Benin, Nigeria.

Odia, A.A (M.Sc ed) She is a PhD Student in the Department of Educational Psychology and Curriculum Studies, Faculty of Education, University of Benin, Nigeria.

\section{References}

Ahiauzu,A. (2010). Entrepreneurship and economic development in Nigeria:The way forward. International Journal of Food, Nutrition and Public Health, 6(2),278-296

Akeredolu-Ale, E.O. (1975). The Underdevelopment of indigenous entrepreneurs in Nigeria. Ibadan, University Press.

Arogundade, B. B. (2011).Entrepreneurship education: An Imperative for sustainable development in Nigeria.Journal of Emerging Trends in Educational Research and Policy Studies (JETERAPS) 2(1):26-29

Ayodele, J.B. (2006). Obstacles to Entrepreneurship development in Nigeria in Omotosho, F., Aluko, T.K.O Wale Awe,O.I. \& Adaramola, G. (ed). Introduction to entrepreneurship development in Nigeria.Ado-Ekiti, UNAD Press.

Duru, M. (2011). Entrepreneurship opportunities and challenges in Nigeria. Business and Management Reveiw 1(1),41-48, March

Drucker, P.F. (1985) Innovation and entrepreneurship practice and principles, New YorkHarper and Row Publishers Inc.

Ebiringa T. (2012). Perspectives: Entrepreneurship Development \& Growth of Enterprises in Nigeria. Entrepreneur Practice Review, 2(2),31-35

Elton, L. (1991): Enterprise in higher education: Work in progress-looking back of the first 3 Years, Education and Training 33(2) 5-9

Ekanem, E.E (2005): Entrepreneurs and natural development. Nigeria Academy of Management Journal, 109-124

Ekanem, E.E (1997): Corporate strategy in the manufacturing sector: A survey of selected companies in Nigeria. Unpublished Ph.D River State University of Science \& Technology, Port Harcourt

Ekwe, O.A. (1992): The structural adjustment programme (SAP) created opportunities for entrepreneurial development in Nigeria in Anyanwu Nigeria Structural Adjustment Programme: A multi-sectional analysis: Enugu, ABIC Book \& Equipment

European Union (2002). Final Report of the Expert Group "Best procedure" Project on Education and Training for Entrepreneurship. Brussels: European Commission Directorate-General for Enterprise. 
Fry, F.L (1992) Entrepreneurship-A planning approach: New York, West Publishing Company

Harrel, K. (2005).Attitude is everything. New York, Harper Collins Publishers

Inegbenebor, A.U (2005): Education for entrepreneurship: Experience of the University of Benin, Benin City, Nigeria. Academy of Management Journal, pp 61-75

Inegbenebor, A.U (2006): The fundamentals of entrepreneurship, Lagos Malthouse Press Limited

Isaacs, E, Visser,K., Friedrich, C \& Brijlal, P. (2007). Entrepreneurship education and training at the further education and training (FET) level in South Africa. South African Journal of Education, 27:613-629

Izedonmi,F.O. I (2009): Model of wealth creation, Benin City, Mindex Publishing Company

Katz, J.A (2003). The chronology and intellectual trajectory of American entrepreneurship education 1876-1999. Journal of Business Venturing, 18(2),283-300.

Kriby,D (2005): A case for teaching entrepreneurship in higher education, http://www.heacademy.ac.uk/resources.asp

Kuratko D.F (2003). Entrepreneurship education: Emerging trends and challenges for the 21st century. Coleman Foundation White Paper Series for the U. S. Association of Small Business and Entrepreneurship. Available at http://www.usabe.org/pdf/CWP2003-kuratko.pdf

Ladzani, W.M. \& Van Vuuren, J.J. (2002). Entrepreneurship training for emerging SMEs in South Africa. Journal of Small Business Management, 40:154-161.

Lemo,T. (2013).Development and the entrepreneurial challenge policy and execution. ThisDay,11 January,2013 Midea, M (2004): Learning to do as a pillar of education and its link to entrepreneurial studies in higher education: European contexts and approaches, higher education

Moreland, N (2004): Entrepreneurship and Higher Education. An Employability Perspective: http://www.heacademy.ac.uk/resources.asp

Morris, H \& Kuratko, F. (2001). Corporate entrepreneurship: Entrepreneurial development within organizations. New York: Harcourt.

Osemeke,M. (2012). Entrepreneurial development and interventionist agencies in Nigeria. International Journal of Business and Social Science,3( 8),255-265

Oteh, A. (2009). The role of entrepreneurship in transforming the Nigerian economy. $7^{\text {th }}$ Convocation Lecture of Igbinedion University, Okada, Edo State , Nigeria

Pakpa, P. (2013). Graduate Internship Scheme (GIS). A paper presented the project director at the closing ceremony of the orientation and employability training for interns and firms at Lagos Airport Hotel on 19th April, 2013

Paul, E.O. (2005). Entrepreneurship education in Ezema P.A.N, Paul E.O.; Anioke B. O., Godwin A.G. Okwuolise, C. A. Eheli,H.U. Anih (ed) Entrepreneurship in vocational education. Enugu: OZYBEL Publishers.

Ndumanya, N.(2012). Entrepreneurship and business plan. Businessday, Monday 30th July. Africa Research Review, 5, 213-226 October

Nwangwu I.O. (2006). Fundamentals of entrepreneurship in educational management. Enugu: Cheston Agency Ltd.

Timmons, J.A. \& Spinelli, S. (2004). New venture creation: Entrepreneurship for the 21 st century. Boston: McGraw Hill Irwin.

Unachukwu, G. O.(2009): Issues and challenges in the development of entrepreneurship education in Nigeria. Volkmann,C. (2004): Entrepreneurship studies. An ascending academic discipline in the twenty-one century.

Vyakarnan, S. (2009).Driving forces of entrepreneurship education in Educating the next wave of entrepreneurs edited by Volkmann,C.,Wilson,K.E.,Mariotti,S., Rabuzzi., Vyakarnan, S. \& Sepulvede,A , World Econmic Forum, Swizerland 